\title{
Duodenal total and ionised calcium secretion in normal subjects, chronic alcoholics, and patients with various stages of chronic alcoholic pancreatitis
}

\author{
J LOHSE AND A PFEIFFER
}

From the 5th Medical Department, Hospital Munich-Schwabing, München, West Germany

SUMmaRY Previous studies have shown increased secretion of total calcium in the duodenal juice of patients with chronic alcoholic pancreatitis compared with healthy subjects. In order to get more detailed information on calcium secretion and pancreatic stone formation in chronic alcoholic pancreatitis, ionised and total calcium concentrations were determined in the duodenal juice of normal subjects, chronic alcoholics, and patients with various stages of chronic alcoholic pancreatitis. Total calcium secretion was in agreement with previously published data. Chronic alcoholics presented a significant increase of ionised calcium. In the course of pancreatitis all calcium fractions increased progressively revealing highest concentrations in patients with severe exocrine insufficiency. In non-calcified and calcified pancreatitis all calcium fractions were identical. It is suggested that the increase of ionised calcium originates from serum ionised calcium passing by diffusion into the damaged pancreatic duct system.

Several authors have observed an increase of calcium secretion in the secretin stimulated duodenal juice of patients with chronic pancreatitis $^{1-9}$ which has been interpreted to be not only due to a decreased secretion independent of exocrine pancreatic enzymes. ${ }^{10}$ Highest concentrations for calcium were. found in the duodenal juice of patients with chronic calcified pancreatitis after secretin ${ }^{1}$ and under exogenous CCK administration. Basal and secretin/CCK stimulated calcium outputs in these patients were significantly enhanced as compared with controls. ${ }^{1}$ It was suggested that enhanced calcium secretion in the duodenal juice of patients with alcoholic pancreatitis is a precondition for calcium carbonate precipitation and subsequent stone formation in the pancreatic ductal system. ${ }^{9}$ Warwick et $\mathrm{al}^{7}$ postulated an increased intrapancreatic calcium pool to be responsible for high concentrations of calcium in the duodenal juice, whereas Goebell et al ${ }^{1}$ suggested that ionised plasma calcium enters the pancreatic duct system by diffusion from serum through damaged duct epithelia characterised by an increased permeability as described by Nakamura et al ${ }^{11}$ in pancreatic tissues of patients with chronic alcoholic

Address for correspondence: Dr Jürgen Lohse, Lembkestr 18, 2400 LübeckTravemünde, West Germany.

Received for publication 17 October 1983. pancreatitis.

The aim of this study was to investigate the secretion of the different calcium fractions in the course of chronic alcoholic pancreatitis.

\section{Methods}

PATIENTS

Seventy patients entered the study and were classified into three groups according to their history and the results of the secretin/CCK test.

\section{Group 1}

Twenty healthy subjects, 11 women and nine men with a mean age of 44 years (range 24-68 years), served as normals (N). They had no history or any clinical signs of alcoholism, gastrointestinal disease, of hyperparathyroidism.

\section{Group 2}

Fifteen chronic alcoholics (A), eight women and seven men with a mean age of 41 years (range 27-71 years), had an alcohol index of more than $100 \mathrm{~g} /$ day for at least five years. They were characterised by a fatty liver, but had no history or biochemical signs of pancreatic affection.

\section{Group 3}

Thirty five patients suffered from chronic alcoholic 
pancreatitis of different stages. They were classified according to the results of the secretin/CCK test into four subgroups: (a) Eight patients (CP), three women and five men with a mean age of 37 years (range 29-47 years), had chronic alcoholic pancreatitis with a typical history of chronic relapsing hyperamylasaemia, hyperlipasaemia accompanied by painful abdominal attacks. They presented a normal secretin/CCK test and were classified as 'early stage' of chronic pancreatitis. (b) Eight patients $\left(\mathrm{NCP}_{\text {mod }}\right)$, one woman and seven men with a mean age of 43 years (range 31-67 years), had chronic alcoholic pancreatitis accompanied by moderate exocrine pancreatic insufficiency characterised by a decrease of two parameters as determined in the secretin/CCK test. (c) Nine patients $\left(\mathrm{NCP}_{\text {sev }}\right)$, one woman and eight men with a mean age of 41 years (range 34-49 years), had advanced alcoholic pancreatitis with severe exocrine insufficiency of all parameters. (d) The remaining 10 patients (CCP), two women and eight men with a mean age of 43 years (range 32-49 years), presented distinct exocrine insufficiency and radiologically visible calcifications in the pancreatic area.

\section{EXPERIMENTAL DESIGN}

After overnight fasting all subjects were intubated with a double luminal Lagerlöf tube under radiological control to localise its exact position in the stomach and duodenum. Pancreatic stimulation was performed by simultaneous intravenous administration of $1 \mathrm{U} / \mathrm{kg} / \mathrm{h}$ secretin (Kabi Diagnostica, Studsvik, Sweden, batch no 69200901) and CCK (Kabi Diagnostica, batch no 169901) respectively (secretin/CCK test). Duodenal and gastric juices were collected separately. The continuously aspirated gastric juice was discarded. Duodenal juice was collected on ice in three 20 minute samples (fraction I-III) for one hour and directly submitted to analysis.

\section{ANALYTICAL DETERMINATIONS}

The volumes of all samples were read to the nearest $0.1 \mathrm{ml}$. Each sample was then analysed for total and ionised calcium concentrations. Finally, in each sample the $\mathrm{pH}$ was determined. $\mathrm{pH}$ values were monitored by a pH electrode (Radiometer, Copenhagen, Denmark). Total calcium concentrations were determined by flame photometry (Eppendorf, Hamburg, West Germany). The concentration of ionised calcium was determined by means of a calcium selective ion exchange electrode (type IS $561-\mathrm{Ca}^{++}$, Philips, Netherlands). The characteristics of ion selective electrodes and techniques of measurements have been described in detail else- where. $^{12-17}$

All measurements were performed at $25^{\circ} \mathrm{C}$. Calcium values are given in concentration terms. The electrode was calibrated with solutions containing different concentrations of $\mathrm{CaCl}_{2}\left(10^{-3}-10^{2}\right.$ $\mathrm{mM})$ but constant concentrations of $\mathrm{NaCl}(141$ $\mathrm{mM}), \mathrm{KCI}(7.5 \mathrm{mM})$ and $\mathrm{MgCl}_{2}(0.25 \mathrm{mM})$, corresponding to the values obtained in human duodenal juice. ${ }^{1819}$ Standard solutions were adjusted to $\mathrm{pH} 7 \cdot 8-8 \cdot 2$ and $\mathrm{pH} 8 \cdot 3-8 \cdot 7$ by triethanolamine respectively ${ }^{20}$ according to the $\mathrm{pH}$ determined in the sample solution. The electrode response was linear over the $0.05-100.00 \mathrm{mM}$ range (Fig. 1). Neglecting the possible effects of other cations within this range the potential difference $\Delta \mathrm{E}$ between unknown and standard solution is given by:

$$
\left[\mathrm{Ca}_{\text {unk }}^{++}\right]=\left[\mathrm{Ca}_{\text {std }}^{++}\right] \times 10^{\Delta \mathrm{E} / \mathrm{S}}
$$

$S$ is the slope of the plot of $\log \left[\mathrm{Ca}^{++}\right]$against millivolt potential obtained from measurements in standard solutions. The measuring accuracy of 59 samples of ionised calcium standard solutions presented a variation coefficient of $4.08 \%$. Outputs for ionized and total calcium were calculated as

$$
\frac{\text { conc } \times \text { vol }}{\mathrm{kg} \text { body weight }}
$$

STATISTICAL ANALYSIS

Values are given as means \pm SEM. Statistical analysis was carried out using the Student's $t$ test for unpaired values.

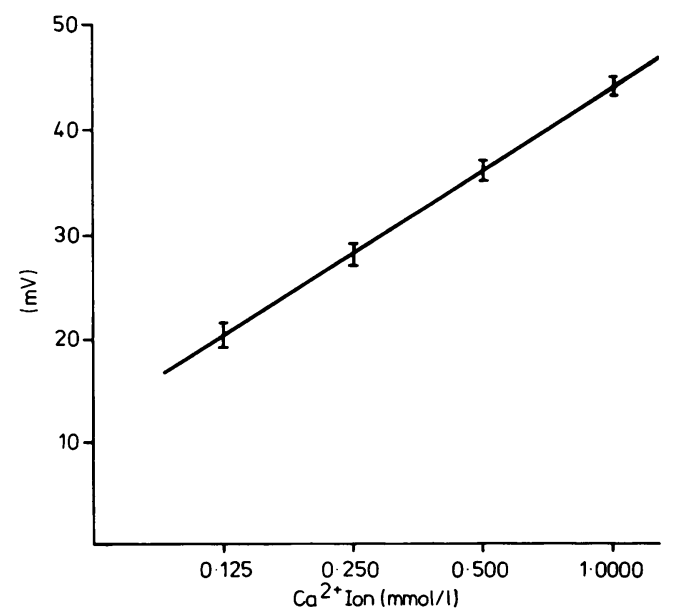

Fig. 1 Calibration line of standard solutions with $\mathrm{pH}$ $7 \cdot 8-8 \cdot 2$. 


\section{Results}

\section{CALCIUM CONCENTRATIONS}

Total and ionised calcium concentrations are shown in Figures 2 and 3. Chronic alcoholism leads to a significant increase in total calcium concentration in fractions II and III and of ionised calcium in all three fractions when compared with normal subjects.

In the early stage of chronic alcoholic pancreatitis (CP), total calcium concentrations are not statistically different from those of normal subjects, whereas ionised calcium values are significantly enhanced in fraction I and II. Comparing alcoholics (A) to CP patients, no difference can be seen for total as well as for ionised calcium concentrations.

In later stages of the disease, $\left(\mathrm{NCP}_{\text {mod }}\right)$ total calcium is raised in fraction II and III and ionised calcium concentrations are increased in all three fractions as compared to normal. Comparing $A$ to $\mathrm{NCP}_{\text {mod }}$ and $\mathrm{CP}$ to $\mathrm{NCP}_{\text {mod }}$ respectively, a significant increase was only found for ionised calcium concentrations in fraction $I$ and II of $\mathrm{NCP}_{\bmod }$ patients $(\mathrm{p}<0.05)$.

For total calcium significant differences are found comparing advanced stages of chronic alcoholic pancreatitis $\left(\mathrm{NCP}_{\text {sev.1 }} \mathrm{CCP}\right)$ with normal subjects. When comparing these two groups with alcoholics, significant higher calcium concentrations are observed $(\mathrm{p}<0.001$ in $\mathrm{I}, \mathrm{p}<0.05$ in II, and $\mathrm{p}<0.005$ in III). Statistical differences are also found for fraction I and II of CP patients $(p<0.005)$ and for $\mathrm{NCP}_{\text {mod }}$ in fraction I $(\mathrm{p}<0.05)$.

$\mathrm{NCP}_{\text {sev }}$ and CCP show significantly enhanced concentrations of ionised calcium compared with normal subjects, chronic alcoholics $(\mathrm{p}<0.001), \mathrm{CP}$ $(p<0.001)$, and $\mathrm{NCP}_{\text {mod }}(\mathrm{p}<0.005)$ in all fractions. Between severe non-calcified $\left(\mathrm{NCP}_{\text {sev }}\right)$ and calcified pancreatitis (CCP) no statistical difference can be observed in respect to their total and ionised calcium concentrations.

Values of bound calcium are shown in Table 1. Bound calcium concentrations in $\mathrm{A}, \mathrm{CP}$, and $\mathrm{NCP}_{\text {mod }}$ were similar to those of normal subjects, except for fraction III of $\mathrm{A}$ and $\mathrm{NCP}_{\text {mod }}$, which presented higher concentrations of bound calcium. In severe exocrine insufficiency $\left(\mathrm{NCP}_{\text {sev }}, \mathrm{CCP}\right)$ bound calcium concentrations were distinctly raised as compared with normal subjects, chronic alcoholics $(\mathrm{p}<0.005)$ in I, $\mathrm{p}<0.05$ in II and III, respectively), to $C P$ in fraction $I(p<0.01)$ and II $(p<0.05)$ and to $\mathrm{NCP}_{\text {mod }}$ in fraction $\mathrm{I}(\mathrm{p}<0.05)$. These significances are similar to those of total calcium concentrations in the duodenal juices. No statistical difference was observed for bound calcium concentrations in the duodenal juice between $\mathrm{A}$ and $\mathrm{CP}$ as well as between $\mathrm{NCP}_{\text {sev }}$ and
Fig. 2 Total calcium concentrations in duodenal juice of normals $(N)$, chronic alcoholics $(A)$, and patients with different stages of chronic alcoholic pancreatitis $(C P$, $\left.N C P_{\text {mod }}, N C P_{\text {sev. }}, C C P\right) . A$, $C P, N C P_{\text {mod }}, N C P_{\text {sei }}, C C P$ vs $N:^{*}=p<0.05,{ }^{* *}=p<0.01$, $* * *=p<0.005, t=p<0.001$; $N S=$ not significant.

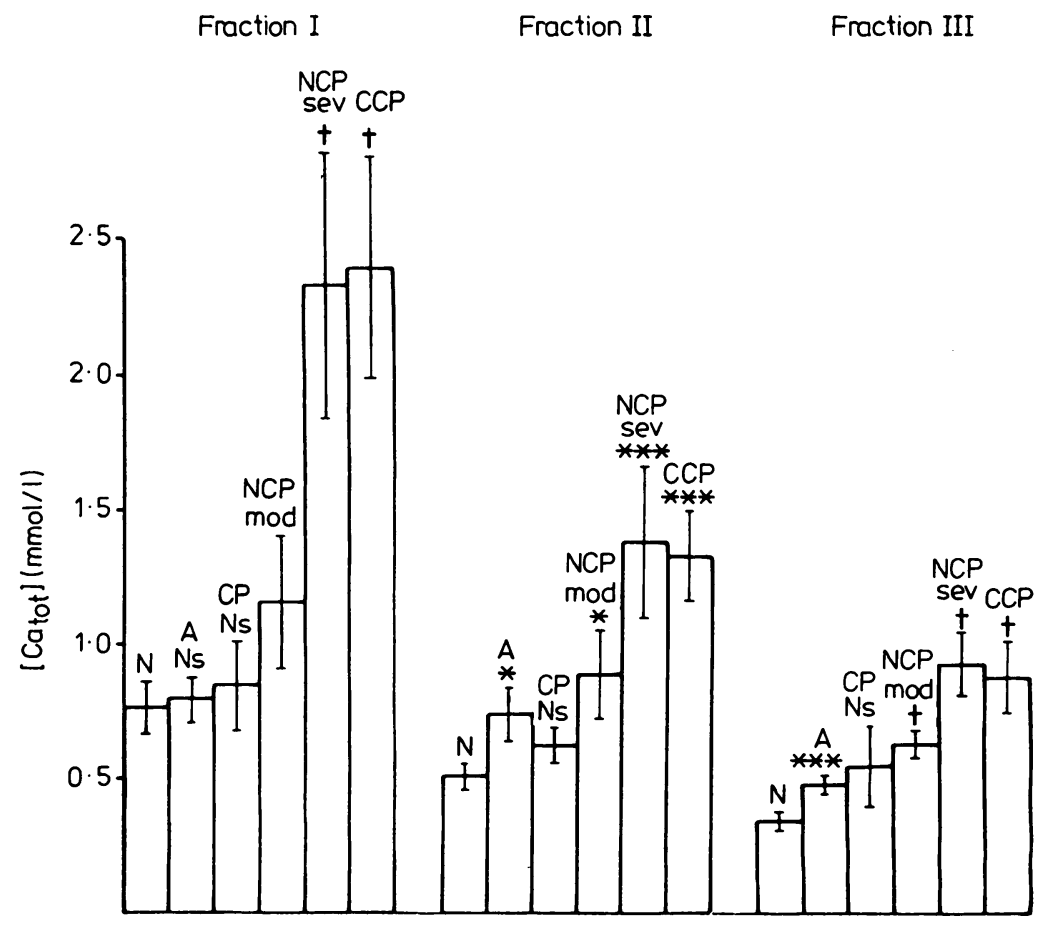


Fig. 3 lonised calcium concentrations in duodenal juice of normals $(N)$, chronic alcoholics $(A)$, and patients with different stages of chronic alcoholic pancreatitis $(C P$, $\left.N C P_{\text {mod }}, N C P_{\text {sev }}, C C P\right) . A$, $C P, N C P_{\text {mod }}, N C P_{\text {sev }}, C C P$ vs $N:^{*}=p<0.05,{ }^{* *}=p<0.01$, $* * *=p<0.005, t=p<0.001$; $N S=$ not significant .

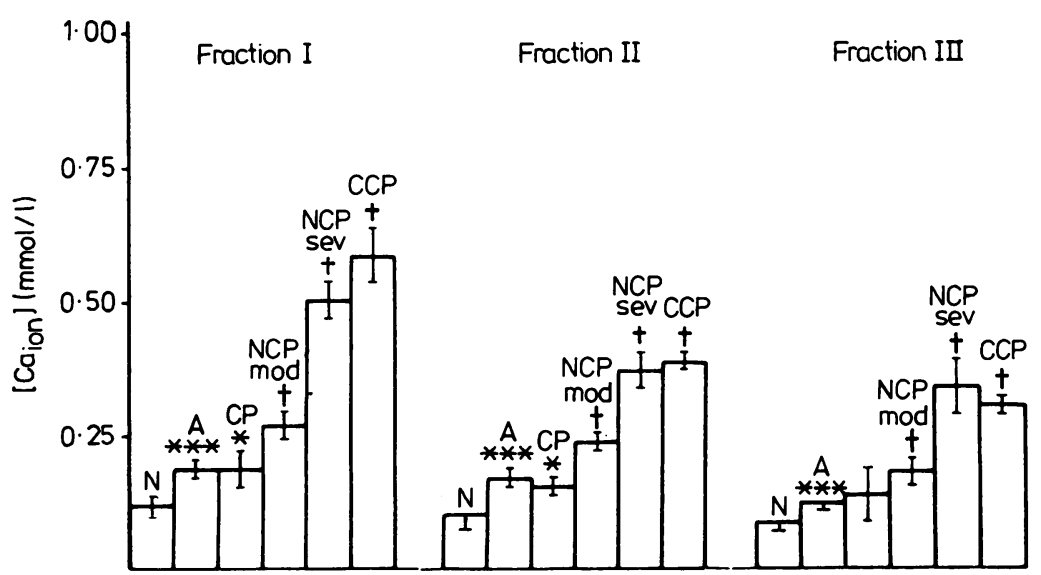

ionised and bound calcium to total calcium outputs. No major differences in the proportionate calcium binding was observed in $\mathrm{A}, \mathrm{CP}$ and $\mathrm{NCP}_{\text {mod. }}$. In fraction III of patients with severe non-calcified pancreatitis $\left(\mathrm{NCP}_{\text {sev }}\right)$ ionised calcium was significantly increased $(p<0.05)$ and the bound calcium fraction was decreased. In CCP patients all fractions showed a significant difference in the proportionate calcium binding showing a significant increase of the ionised calcium fraction.

\section{Discussion}

The applied method of ionised calcium determination in the duodenal juice presented reliable and reproducible results after calibration with appropriate standard solutions. Simultaneous determination of total and ionised calcium concentrations in the same sample allowed calculation of the bound calcium fraction. The application of $\mathrm{Ca}^{++}$selective electrodes is an appropriate method to study in detail calcium secretion in the duodenal juice.

Total calcium concentrations in the duodenal juice were in agreement with those reported previously by Goebell et $a l^{1}$ and Warwick et al, ${ }^{7}$ who found similar values in normal subjects and patients with chronic calcified pancreatitis. Enhanced levels of total calcium concentrations in patients with moderate and severe non-calcifying pancreatitis as shown in the present study, are in accordance with preceding results ${ }^{4} 7$ but are in contrast with observations of reduced total calcium concentrations in non-calcifying pancreatitis. ${ }^{1}$

The increase of total calcium outputs in the duodenal juice of patients suffering from chronic alcoholic pancreatitis are similar to those reported earlier $^{8} 9$ indicating that raised duodenal calcium secretion is not merely a reflexion of reduced 
Table 3 Percentage difference of ionised and bound to total calcium within each group

\begin{tabular}{|c|c|c|c|c|c|c|}
\hline \multirow[b]{2}{*}{ Patients } & \multicolumn{2}{|l|}{ Fraction I } & \multicolumn{2}{|l|}{ Fraction II } & \multicolumn{2}{|l|}{ Fraction III } \\
\hline & $C a_{i o n}$ & $C a_{\text {hound }}$ & $C a_{i o n}$ & $C a_{\text {hound }}$ & $C a_{i o n}$ & $C a_{\text {hound }}$ \\
\hline$N(n=20)$ & $18 \cdot 9 \pm 2 \cdot 1$ & $81 \cdot 1 \pm 2 \cdot 1$ & $21 \cdot 9 \pm 2 \cdot 6$ & $78 \cdot 1 \pm 2 \cdot 6$ & $26 \cdot 2 \pm 2 \cdot 3$ & $73 \cdot 8 \pm 2 \cdot 3$ \\
\hline$A(n=15)$ & $24 \cdot 7 \pm 2 \cdot 1 \ddagger$ & $75 \cdot 3 \pm 2 \cdot 0$ & $25 \cdot 5 \pm 3.3 \ddagger$ & $74 \cdot 5 \pm 3 \cdot 3$ & $25 \cdot 2 \pm 2 \cdot 0 \ddagger$ & $74 \cdot 8 \pm 2 \cdot 0$ \\
\hline$C P(n=8)$ & $26 \cdot 8 \pm 6 \cdot 4 \ddagger$ & $73 \cdot 2 \pm 6 \cdot 4$ & $25 \cdot 4 \pm 3 \cdot 0 \ddagger$ & $74 \cdot 6 \pm 3 \cdot 0$ & $22 \cdot 9 \pm 1 \cdot 9 \ddagger$ & $77 \cdot 1 \pm 1 \cdot 9$ \\
\hline$N C P_{\text {mod }}(n=8)$ & $28 \cdot 3 \pm 5 \cdot 7 \ddagger$ & $71 \cdot 7 \pm 5 \cdot 7$ & $31 \cdot 4 \pm 5 \cdot 3 \ddagger$ & $68 \cdot 6 \pm 5 \cdot 3$ & $27 \cdot 4 \pm 4 \cdot 3 \ddagger$ & $72 \cdot 6 \pm 4 \cdot 3$ \\
\hline $\mathrm{NCP}_{\text {sev }}(n=9)$ & $29 \cdot 6 \pm 6 \cdot 8 \ddagger$ & $70 \cdot 4 \pm 6 \cdot 8$ & $32 \cdot 4 \pm 5 \cdot 2 \ddagger$ & $67 \cdot 6 \pm 5 \cdot 2$ & $38 \cdot 4 \pm 4 \cdot 7^{*}$ & $61 \cdot 6 \pm 4 \cdot 7$ \\
\hline $\operatorname{CCP}(n=9)$ & $29 \cdot 4 \pm 4 \cdot 0^{*}$ & $70 \cdot 6 \pm 4 \cdot 0$ & $32 \cdot 5 \pm 4 \cdot 4^{*}$ & $67 \cdot 5 \pm 4 \cdot 4$ & $38 \cdot 6 \pm 2 \cdot 0^{* * *}$ & $61 \cdot 4 \pm 2 \cdot 0$ \\
\hline
\end{tabular}

${ }^{*}=\mathrm{p}<0 \cdot 05,{ }^{* * *}=\mathrm{p}<0.005$ vs $\mathrm{N} ; \ddagger=$ not significant.

volume secretion by the diseased pancreas, but represents an increase in the absolute amount of calcium flux into the duodenum. The distinctly raised total calcium outputs in chronic alcoholics, which are similar to those of severe non-calcified and calcified pancreatitis may be explained by the increased volume secretion as compared with normal subjects.

The decrease of all calcium fractions (concentrations and outputs) with time after stimulation may be interpreted as a 'washout' phenomenon.

Gall bladder bile with its high calcium concentration $^{118}$ (and unpublished results) may be excluded as the predominant source of enhanced calcium concentrations in the duodenum of patients with reduced volume secretion, since Regan et al ${ }^{8}$ showed that the rise of duodenal calcium concentration in chronic alcoholic pancreatitis is independent of the presence or absence of the gall bladder.

The increase of duodenal total calcium concentrations in chronic alcoholics and the progressive increase in the course of chronic alcoholic pancreatitis is the result of an increased secretion of ionised as well as of bound calcium. As no major differences were found in the proportionate calcium binding for $\mathrm{A}, \mathrm{CP}$, and $\mathrm{NCP}_{\text {mod }}$ it is suggested that all three calcium fractions rise in parallel. Modifications of the proportionate calcium binding were observed in fraction III of $\mathrm{NCP}_{\text {sev }}$ and in all fractions of CCP in favour of the ionised calcium fraction. The fact that about $38 \%$ of total calcium was ionised in fraction III of $\mathrm{NCP}_{\text {sev }}$ and CCP patients, which is near to that of ionised serum calcium $(40-45 \%),{ }^{14} 21$ suggests a direct flux of calcium from serum into the pancreatic juice. It is possible that this serum calcium passes through ductal lesions by diffusion into the ductal system. Those lesions have been shown by Nakamura et al. ${ }^{11}$ Another source of raised ionised calcium concentrations could be a decrease of pancreatic enzyme bound calcium in exocrine insufficiency and a decreased citrate secretion $^{22}$ which has been shown in chronic calcified pancreatitis. As enzyme concentrations in chronic alcoholics and patients with early stages of alcoholic pancreatitis are in the range of normals, raised ionised calcium concentrations in these groups cannot originate from a decrease of enzyme bound calcium. As no linear relationship was found between $\mathrm{pH}$ and ionised calcium concentrations in all groups it is suggested that moderate $\mathrm{pH}$ variations in the duodenal juice do not affect ionised calcium concentrations.

The increase of bound calcium in the course of chronic alcoholic pancreatitis, which is accompanied by a progressive decrease of enzyme secretion, may suggest that other substances than pancreatic enzymes are responsible for calcium binding in the duodenal juice. Those substances could be serum proteins (albumin, immunoglobulins) which occur in higher concentrations in the duodenal juice of patients with chronic alcoholic pancreatitis. ${ }^{23} 24$ Therefore we assume that not only ionised serum calcium but also serum proteins could pass through ductal lesions in the pancreatic ducts.

Increased calcium concentrations in the pancreatic juice are considered to be a major cause of pancreatic lithogenicity. As increased calcium concentrations are already present in the duodenal juice of chronic alcoholics and patients with early stages of alcoholic pancreatitis, we suggest that additional factors must be involved in pancreatic stone formation. This assumption is based on the observation that no difference in calcium secretion was found between severe non-calcified and calcified pancreatitis. We have recently isolated a so far unknown secretory protein from human pancreatic stones ('stone protein') $)^{25} 26$ with high calcium binding affinity ${ }^{27}$ which was shown to inhibit specifically the precipitation and nucleation of calcium carbonate in vitro. ${ }^{28}$ Its concentration in pure pancreatic juice of patients with advanced alcoholic pancreatitis is distinctly decreased ${ }^{29}$ and may therefore favour calcium carbonate precipitation and pancreatic stone formation in the supersaturated pancreatic juice. 


\section{References}

1 Goebell H, Bode Ch, Horn HD. Einfluß von Sekretin und Pankreozymin auf die Calciumsekretion im menschlichen Duodenalsaft bei normaler und gestörter Pankreatsfunktion. Klin Wochenschr 1970; 48: 1330-9.

2 Sturm WB, Spiro HM, Hersh T. Studies on the relationship of pancreatic juice calcium to calcific pancreatitis. Gastroenterology 1970; 58: 998.

3 Baltzer G, Goebell $H$, Müller-Reinhardt $B$. Magnesium und Calcium im Duodenalsaft bei verschiedenen Funktionszuständen des Pankreas und beim Primären Hyperparathyreoidismus. Klin Wochenschr 1974; 52: 74-9.

4 Hansky J. Calcium content of duodenal juice. Am J Dig Dis 1967; 12: 725-33.

5 Nimmo J, Finlayson NDC, Smith AF, Shearman DJC. The production of calcium and magnesium during pancreatic function tests in health and disease. Gut 1970; 11: 163-6.

6 Goebell H, Baltzer G, Schlott KA, Bode Ch. Parallel secretion of calcium and enzymes by the human pancreas. Digestion 1973; 8: 336-46.

7 Warwick RRG, Thothill P, Percy-Robb IW, Shearman DJC. The calcium concentration in pancreatic secretion in chronic pancreatitis and carcinoma of the pancreas. Scand J Gastroenterol 1973; 8: 301-5.

8 Regan PT, Malagelada JR, DiMagno EP. Duodenal calcium outputs in health and pancreatic disease. Gut 1980; 21: 614-8.

9 Clain JE, Barbezat GO, Marks IN. Exocrine pancreatic enzyme and calcium secretion in health and pancreatitis. Gut 1981; 22: 355-8.

10 Gullo L. Sarles H, Mott C, Tiscornia O. Pancreatic secretion of calcium in healthy subjects and various diseases of the pancreas. Rendic Gastroenterol 1974; 6: 35-44.

11 Nakamura K, Sarles H, Payan H. Three dimensional reconstruction of the pancreatic ducts in chronic 1 pancreatitis. Gastroenterology 1972; 62: 942-9.

12 Camann K. Das Arbeiten mit ionenselektiven Elektroden. Berlin, Heidelberg, New York: Springer Verlag, 1973.

13 Moore EW. Studies with ion-exchange calcium electrodes in biological fluids: some applications in biomedical research and clinical medicine. In: Durst RA, ed. Ion selective electrodes. Washington: National Bureau of Standards, 1969; 215-86.

14 Moore EW. Ionized calcium in normal serum, ultrafiltrates and whole blood determined by ion-exchange electrodes. J Clin Invest 1970; 49: 318-34.

15 Harned HS, Owen BB. The physical chemistry of electrolytic solutions. New York: Reinhold Publishing
Corporation, 1963; 488

16 Klotz IM. Chemical thermodynamics. Englewood Cliffs: Prentice-Hall Inc, 1950.

17 Moore EW. Hydrogen and cation analysis in biological fluids in vitro. In: Eisenmann G, ed. Glass electrodes for hydrogen and other cations. Principles and practice. New York: M Dekker Inc, 1967; 412-41.

18 Forell MM, Stahlheber H. Gallenwege und exokrines Pankreas. In: Siegenthaler W, ed. Klinische Pathophysiologie. Stuttgart: Georg Thieme Verlag, 1976: 825-45.

19 Gülzow M. Biochemie des Pankreas. In: Demling L. ed. Klinische Gastroenterologie. Stuttgart: Georg Thieme Verlag, 1973: 900-18.

20 Fuchs C. Ionenselektive Elektroden in der Medizin. Stuttgart: Georg Thieme Verlag, 1976.

21 Fuchs C, Paschen K, Spiekermann PG, Westberg CV. Bestimmung des ionisierten Calciums im Serum mit einer ionenselektiven Durchflußelektrode: Methode und Normalwerte. Klin Wochenschr 1972; 50: 824-32.

22 Lohse J, Hümmer H, Pfeiffer A, Kuntzen O, Kaess H. Ionized calcium and citrate secretion in the duodenal juice of normals and patients with chronic calcifying pancreatitis. 12th Meeting Europ Pancr Club, Copenhagen 1979. Dan Med Bull 1979; 26: 35.

23 Lohse J, Kaess H. Lactoferrin, Albumin und Gammaglobuline im Duodenalsaft; diagnostische Wertigkeit bei chronisch alkoholischer Pankreatitis. Verh Dtsch Ges Inn Med 1981; 87: 1021-4.

24 Clemente F, Ribeiro R, Figarella C, Sarles H. Albumine, IgG et IgA dans le suc pancréatique humain normal chez l'adulte. Clin Chim Acta 1971; 33: 317-24.

25 De Caro A, Lohse J, Sarles H. Characterization of a protein isolated from pancreatic calculi of men suffering from chronic calcifying pancreatitis. Biochem Biophys Res Comm 1979; 87: 1176-82.

26 Lohse J, Dörner M, Wurster K, Kaess H. Immunohistological localization of the low molecular protein from pancreatic stones in pancreatic tissue. Krakow: 13th Meeting Europ Pancr Club, 1981, May 15th

27 Lohse J, Krämer R, Kaess H. The binding of calcium to pancreatic-stone-protein. Luxemburg: 16th Meeting Europ Soc Clin Invest, 1982, April 17th

28 Multigner L, De Caro A, Lombardo D, Campése D, Sarles H. Contrôle de la nucléation et de la croissance cristalline du carbonate de calcium par la protéine du calcul pancréatique humain. Gastroenterol Clin Biol 1982; 6: 55A.

29 Sarles H, Multigner L, De Caro A, Campése D, Lombardo D. Une baisse de sécrétion de la protéine des calculs est-elle la cause, unique ou associée á un trouble nutritionnel, des pancréatites chroniques calcifiantes? Gastroenterol Clin Biol 1982; 6: 602-3. 